\title{
TESTING AND VALIDATION OF METHODS FOR THE DIAGNOSIS AND RECOMMENDATION INTEGRATED SYSTEM FOR SIGNAL GRASS
}

\author{
Cristiane Prezotto Silveira ${ }^{1}$; Gilmar Ribeiro Nachtigall ${ }^{1,2}$; Francisco Antonio Monteiro ${ }^{3 *}$ \\ ${ }^{1}$ USP/ESALQ - Programa de Pós-Graduação em Solos e Nutrição de Plantas. \\ ${ }^{2}$ Embrapa Uva e Vinho, C.P. 130 - 95700-000 - Bento Gonçalves, RS - Brasil. \\ ${ }^{3}$ USP/ESALQ - Depto. de Solos e Nutrição de Plantas, C.P. 9 - 13418-900 - Piracicaba, SP - Brasil. \\ *Corresponding author <famontei@esalq.usp.br>
}

\begin{abstract}
The Diagnosis and Recommendation Integrated System (DRIS) allows the interpretation of results of leaf analysis through relationships among nutrients, instead of the absolute and isolated concentration of each one, as it is used by the criterion of sufficiency range. The objective was to evaluate three procedures of calculation of DRIS indices, and to verify the efficiency of DRIS as interpretation method for the results of Brachiaria decumbens (Signal grass). The study was developed with the results of six experiments carried out in a greenhouse at Piracicaba, SP, with nutrient solution. Concentrations of N, P, K, Ca, Mg, S, Cu, Fe, $\mathrm{Mn}$, and $\mathrm{Zn}$ were used in the samples of recently expanded leaf laminae of the grass. The validation of the DRIS method used results from an experiment with nitrogen and sulfur rates applied to the same grass from the Mundo Novo farm, Brotas, SP. DRIS indices were calculated according to two criteria to choose the ratio order of nutrients ( $\mathrm{F}$ value and $\mathrm{R}$ value) and three ways to calculate the nutrient functions (methods of Beaufils, Jones, and Elwali \& Gascho). Nutritional Balance Index (NBI), calculated according to the generated norms, presented negative and significant correlation coefficients with the productivity in the combinations of methods tested and DRIS methods proposed by Beaufils, Jones and Elwali \& Gascho were efficient in detecting concentrations that show nutrients deficiency or excess.
\end{abstract}

Key words: Brachiaria decumbens, DRIS, foliar diagnosis, nutritional balance

\section{CALIBRAÇÃO DO MODELO E VALIDAÇÃO DO SISTEMA INTEGRADO DE DIAGNOSE E RECOMENDAÇÃO PARA O CAPIM-BRAQUIÁRIA}

\begin{abstract}
RESUMO: O Sistema Integrado de Diagnose e Recomendação (DRIS) permite a interpretação dos resultados de análise foliar, utilizando relações entre nutrientes, ao invés da concentração absoluta e isolada de cada um deles, utilizada pelo critério de faixa de suficiência. Objetivou-se avaliar três procedimentos de cálculo dos índices DRIS, bem como verificar a eficiência do DRIS como método de interpretação de resultados de análises de folhas da Brachiaria decumbens (capim-Braquiária). O estudo foi desenvolvido com os resultados de seis experimentos realizados em casa-de-vegetação em Piracicaba, SP, com solução nutritiva. Foram empregadas as concentrações de N, P, K, Ca, Mg, S, Cu, Fe, Mn e Zn nas amostras de lâminas foliares recémexpandidas do capim. Para a validação do método DRIS foram utilizados resultados de um experimento com aplicação de doses de nitrogênio e enxofre realizado com o mesmo capim proveniente da Fazenda Mundo Novo, em Brotas, SP. Os índices DRIS foram calculados por dois critérios para escolha da ordem da razão dos nutrientes (valor F e valor R) e três formas de cálculo das funções dos nutrientes (métodos de Beaufils, Jones e Elwali \& Gascho). O Índice de Balanço Nutricional (IBN), calculado a partir das normas geradas, apresentou coeficientes de correlação negativos e significativos com a produtividade nas combinações de métodos testados e os métodos DRIS propostos por Beaufils, Jones e Elwali \& Gascho foram eficientes em detectar concentrações que revelam a deficiência ou o excesso dos nutrientes.

Palavras-chave: Brachiaria decumbens, DRIS, diagnose foliar, equilíbrio nutricional
\end{abstract}

\section{INTRODUCTION}

The Diagnosis and Recommendation Integrated System (DRIS) is a method of nutritional diagnosis for crops based on the calculation of an index for each nutrient. These indices are expressed by positive or negative values, indicating that the nutrient is in excess or in deficiency in relation to the others, respectively. The closer to zero the indices of all the nutrients, the closer the crop will be to its nutritional balance (Jones, 1981; Beverly, 1991).

DRIS norms are established from a population with high productivity, denominated reference population, is selected from a larger population and inside a group 
of data also strictly selected. The databases to obtain the norms may vary in size according to premises to be adopted in the method, and they have to be uniform with the characteristics of the crop (Letzsch \& Sumner, 1984). The population or database chosen for the definition of norms have to be subdivided into two sub-populations or categories: one constituted of normal plants, or reference population, with high productivity; and another, with abnormal plants, or non-reference population, with smaller productivity than the established one (Beaufils, 1973; Beverly, 1991).

In the calculation of functions of nutrient ratios, three methods have been used: a) the original method of Beaufils (1973); b) the method of Jones (1981); c) the method of Beaufils (1973) modified by Elwali \& Gascho (1984). DRIS even provides an additional index, the Nutritional Balance Index (NBI), that corresponds to the calculation of the sum of all the DRIS indices irrespective of sign. The larger the value of the sum, the greater will be the indication that the crop is in nutritional imbalance, therefore presenting lower productivity.

The objective in this paper was to evaluate three procedures for calculating DRIS indices, as well as to verify the efficiency of DRIS as a method for improving the interpretation of analysis results of recently expanded leaf laminae of Signal grass in relation to the method of nutritional diagnosis based on the criterion of sufficiency range.

\section{MATERIAL AND METHODS}

This work was accomplished with results of six experiments with the forage grass Brachiaria decumbens, grown in silica with nutrient solution, carried out in greenhouse at Piracicaba, SP. The plants of these experiments underwent two growth periods, and the concentrations of nitrogen, phosphorus, potassium, calcium, magnesium, sulfur, iron, manganese, copper, and zinc were determined in the sampled tissue according to the methodology presented by Sarruge \& Haag (1974). For the establishment of DRIS norms for Signal grass, the methodology described by Silveira et al. (2005) was used. Specific norms for the results related to the first and the second growth periods of the plants were also obtained.

Two approaches were assessed to choose the ratio order of the nutrients: the one proposed by Nick (1998) - R value - and the other described by Letzsch (1985) and Walworth \& Sumner (1987) - F value. DRIS indices for nutrients were calculated using the procedures proposed by Beaufils (1973), Jones (1981) and Elwali \& Gascho (1984). The DRIS index I for the nutrient A was obtained as follows:

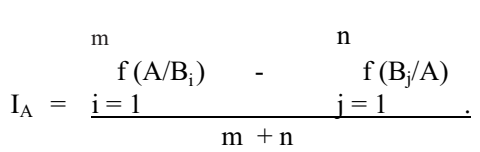

Beaufils (1973):

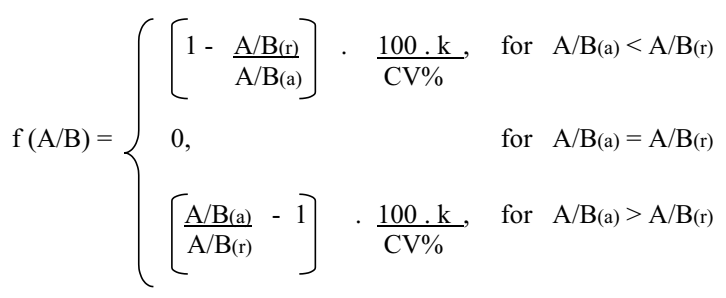

Jones (1981):

$\mathrm{f}(\mathrm{A} / \mathrm{B})=(\mathrm{A} / \mathrm{B}(\mathrm{a})-\mathrm{A} / \mathrm{B}(\mathrm{r})) \mathrm{k} / \mathrm{s}$

Elwali \& Gascho (1984):

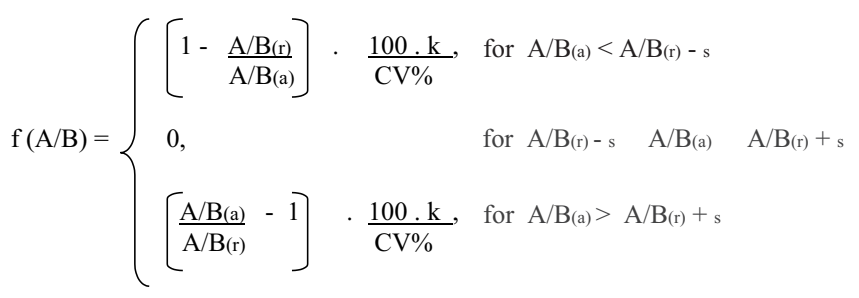

where: $\mathrm{A} / \mathrm{B}(\mathrm{a})=$ relation between the concentration of nutrient $A$ and $B$ in the sample; $A / B(r)=$ relation between the concentration of nutrient $\mathrm{A}$ and $\mathrm{B}$ in the reference population; $\mathrm{CV} \%=$ variation coefficient for the relation, $\% ; \mathrm{s}=$ standard deviation in the relation; $\mathrm{k}=$ constant of sensitivity.

The Nutritional Balance Index (NBI) was calculated through the sum of the absolute values of the indices generated for the sample. This index can be useful to the indication of the plant nutritional status, without hinting their causes. The higher the sum value, the larger the indication of plant nutritional unbalance (Mourão Filho, 2004). The Nutritional Balance Index was obtained for each nutrient of each sample according to the equation:

$\mathrm{NBI}=|\operatorname{Index} \mathrm{A}|+|\operatorname{Index} \mathrm{B}|+\ldots .+|\operatorname{Index} \mathrm{N}|$

The Average Nutritional Balance Index (NBIa) was calculated through the sum of the absolute values of the indices generated for each nutrient, for each sample, divided by the number of nutrients participating in the calculation, according to the equation:

$\mathrm{NBIa}=(|\operatorname{Index} \mathrm{A}|+|\operatorname{Index~B}|+\ldots .+|\operatorname{Index} \mathrm{N}|) / \mathrm{N}$ 
To evaluate the efficiency of the DRIS method in the nutritional diagnosis of Signal grass, the median concentrations of the nutrients in the laminae of recently expanded leaves obtained in another experiment carried out by Mattos (2001) were used. Such Signal grass pasture was established at the Mundo Novo farm, in BrotasSP, and that study had the combinations of four nitrogen rates $\left(0 ; 50 ; 100\right.$; and $\left.200 \mathrm{mg} \mathrm{dm}^{-3}\right)$ with three sulfur rates $\left(0 ; 30\right.$; and $\left.60 \mathrm{mg} \mathrm{dm}^{-3}\right)$, in a complete randomized block design $(n=4)$.

The diagnosis or evaluation of leaf concentration of nutrients for Signal grass was accomplished through the range of nutrients concentration criterion by using arbitrary patterns for the classification of the nutrients (Table 1), and through DRIS, using the three methods of functions calculations. The consistency of the diagnosis was tested through the comparison among these three diagnosis approaches. For the Range of Nutrients Concentration Criterion, three classes were used: deficiency, adequate, and excess. For the nutritional diagnosis using the DRIS method, the methodology proposed by Wadt (1996) was used, as well as three classes established from the DRIS Indices of the nutrient $\left(\mathrm{I}_{\mathrm{Nut}}\right)$ and the Average Nutritional Balance Index (NBIa), assuming:

$\begin{array}{ll}\text { Defficient }=\mathrm{I}_{\text {Nut. }}<0 \quad \text { and } & \left|\mathrm{I}_{\text {Nut. }}\right|>\text { NBIa } \\ \text { Adequate }=\left|\mathrm{I}_{\text {Nut. }}\right| \leq \text { NBIa } & \\ \text { Excess }=\mathrm{I}_{\text {Nut. }}>0 \quad \text { and } & \left|\mathrm{I}_{\text {Nut. }}\right|>\text { NBIa }\end{array}$

Table 1 - Critical level of nutrients in laminae of recently expanded leaves of Brachiaria decumbens, arbitrarily defined by the Sufficiency Range Criterion. ${ }^{1}$

\begin{tabular}{lccl}
\hline \multirow{2}{*}{ Nutrient } & \multicolumn{3}{c}{ Sufficiency Range $^{1}$} \\
\cline { 2 - 4 } & Deficient & Adequate & Excess \\
\hline $\mathrm{N}\left(\mathrm{g} \mathrm{kg}^{-1}\right)$ & $<15$ & 15 to 20 & $>35.5$ \\
$\mathrm{P}\left(\mathrm{g} \mathrm{kg}^{-1}\right)$ & $<1.0$ & 1.0 to 1.5 & $>2.3$ \\
$\mathrm{~K}\left(\mathrm{~g} \mathrm{~kg}^{-1}\right)$ & $<15$ & 15 to 25 & $>35$ \\
$\mathrm{Ca}\left(\mathrm{g} \mathrm{kg}^{-1}\right)$ & $<2.5$ & 3.0 to 6.0 & $>9.0$ \\
$\mathrm{Mg}\left(\mathrm{g} \mathrm{kg}^{-1}\right)$ & $<2.0$ & 2.0 to 5.0 & $>6.0$ \\
$\mathrm{~S}\left(\mathrm{~g} \mathrm{~kg}^{-1}\right)$ & $<0.8$ & 0.8 to 1.6 & $>3.2$ \\
$\mathrm{Cu}\left(\mathrm{mg} \mathrm{kg}^{-1}\right)$ & $<2.0$ & 2.0 to 8.0 & $>10$ \\
$\mathrm{Fe}\left(\mathrm{mg} \mathrm{kg}^{-1}\right)$ & $<25$ & 30 to 150 & $>250$ \\
$\mathrm{Mn}\left(\mathrm{mg} \mathrm{kg}^{-1}\right)$ & $<25$ & 30 to 50 & $>100$ \\
$\mathrm{Zn}\left(\mathrm{mg} \mathrm{kg}^{-1}\right)$ & $<13$ & 20 to 30 & $>40$ \\
\hline
\end{tabular}

${ }^{1}$ Values obtained from Monteiro et al. (1995); Santos, A. (1997); Mattos (1997) and Monteiro (2004) for the laminae of recently expanded leaves, and from Gallo et al. (1974) and Werner et al. (1996) for the new leaves of Signal grass.
The DRIS indices for the nutrients were calculated using the software Microsoft Excel ${ }^{\mathrm{TM}}$ spreadsheet. To evaluate the efficiency of the three methods used, considering the two approaches to choose the ratio order of the nutrients, NBI was related to the relative dry mass production and verified the significance of the correlation coefficient, using the procedure "General Linear Models" (GLM) of the SAS statistical package (SAS Institute, 2000).

\section{RESULTS AND DISCUSSION}

Several authors used the determination coefficient in the relationship between the Nutritional Balance Index (NBI) and the productivity to obtain the best method to calculate the DRIS indices (Santos, W., 1997; Mourão Filho \& Azevedo, 2003). It is expected that the lower the $\mathrm{NBI}$, the better the nutritional balance and the greater the crop productivity. The relationships between the NBI values and the relative dry mass production of Signal grass and the values obtained from the combinations of choice criteria and ratio order between nutrients and DRIS methods are presented in Figures 1 to 3. This study evaluated the relationships for each grass growth by using either the norm obtained for the growth itself or the general norm with the results of both growths.

Even though the correlation coefficients were significant in all combinations of methods, the relationships between NBI and the relative dry mass production obtained in the second growth presented lower correlation coefficients than the ones in the first growth, regardless the DRIS norm used. The relationships were coherent with low values of NBI occurring when the productivity varied from low to high, while high NBI values were only associated to low productivity, as stated by Sumner (1977).

The correlation coefficients between the NBI values and productivity of Signal grass, although statistically significant, were low and varied from 0.39 to 0.74 . This is probably related to the fact that for the relationship NBI $\times$ productivity, the productivity variation was also dependent on other non nutritional factors. Relationships between NBI and productivity with high dispersion of points in studies to generate DRIS norms, originating relatively low $\mathrm{R}^{2}$ values, were also obtained by Wadt et al. (1998) for eucalyptus and Wadt et al. (1999) for coffee. In both cases, it was possible to observe that high values of NBI only occurred in low productivity, as it was also found for Signal grass.

Comparing the combinations of criteria of choice of ratios among nutrients ( $\mathrm{R}$ and $\mathrm{F}$ values) and methods to calculate DRIS indices, it was observed that the fittings between the NBI values and productivity were similar in all the cases. In studies comparing DRIS methods for citrus in the State of São Paulo, Santos, W. (1997) verified that the Jones method was better than the others. 


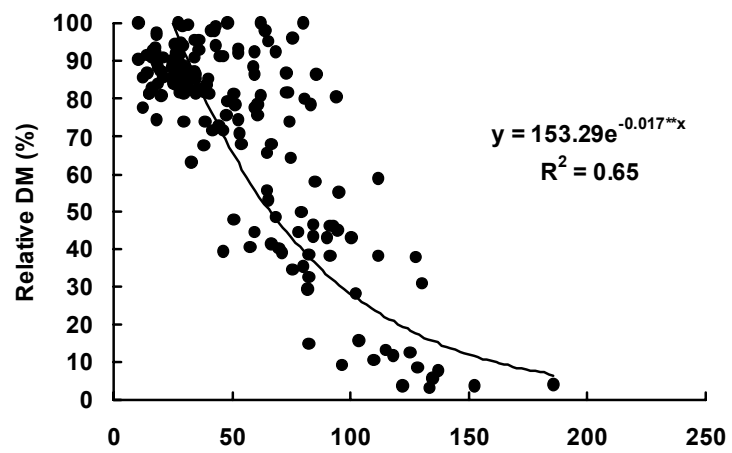

a)

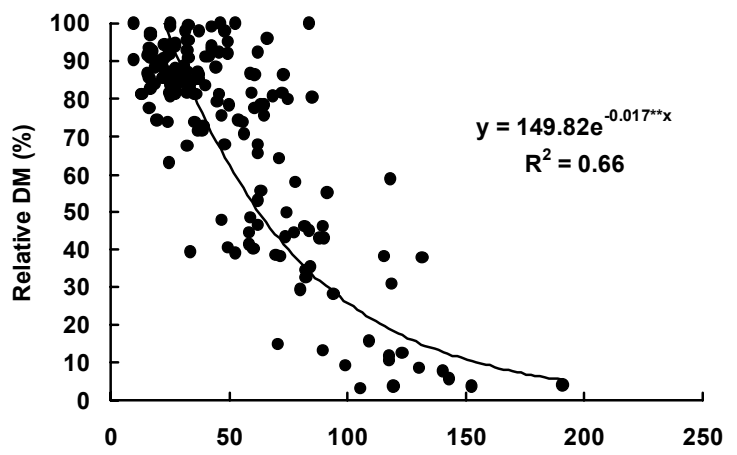

b)

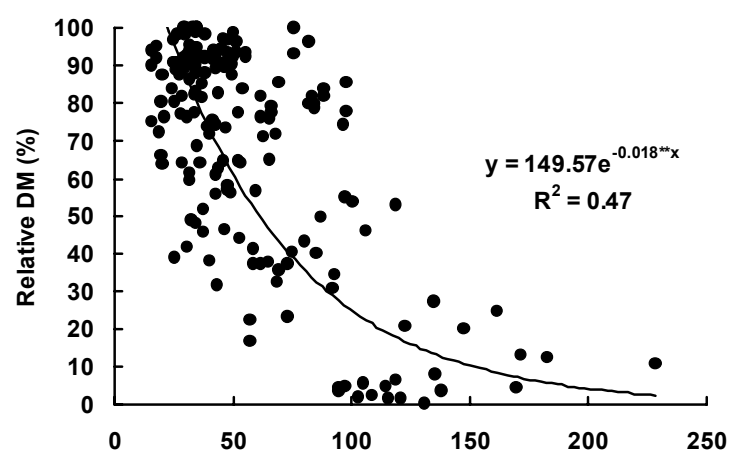

c)

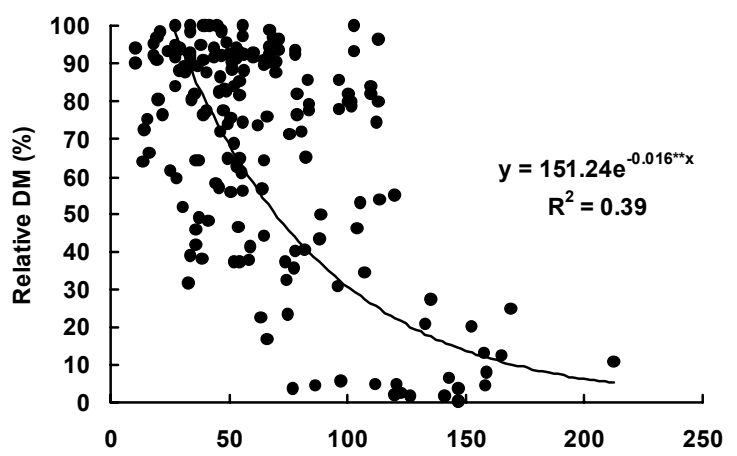

d)

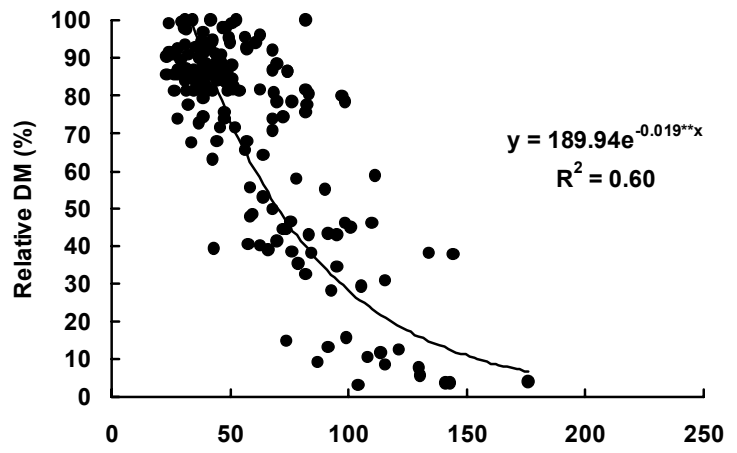

a)

NBI Beaufils $R$

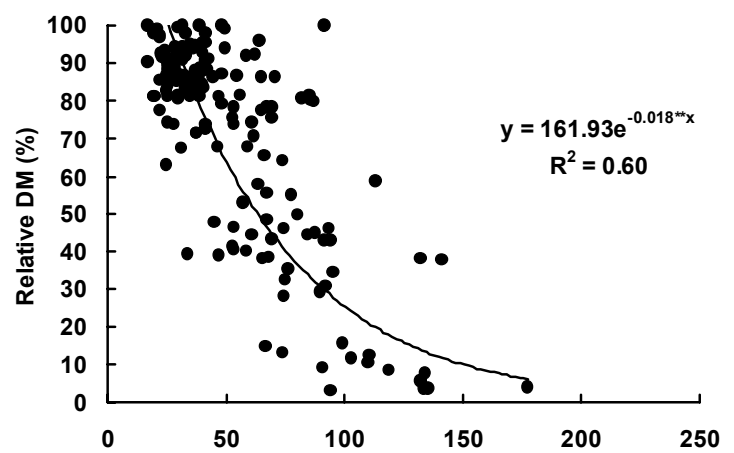

b)

NBI Beaufils $R$

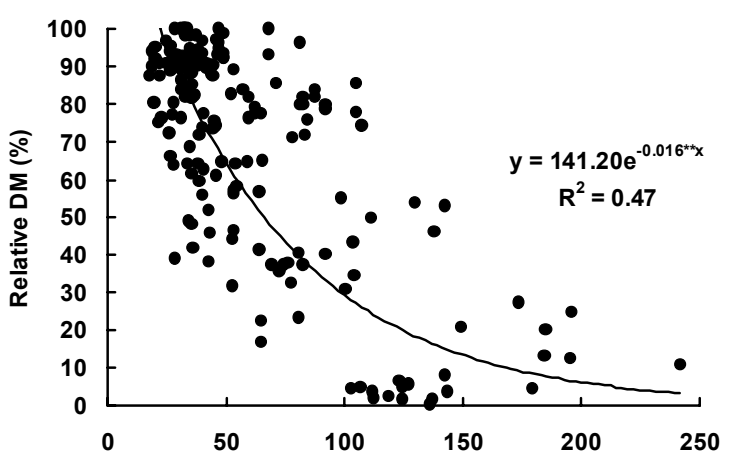

c)

NBI Beaufils $R$

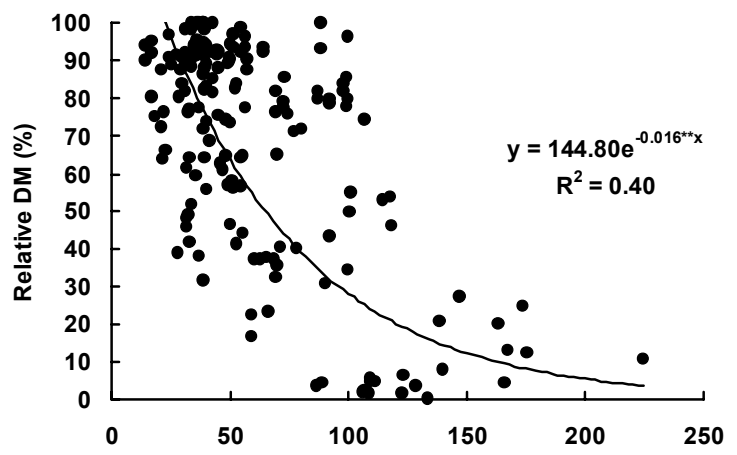

d)

NBI Beaufils $R$

Figure 1 - Relationship between the relative dry mass (DM) production of Signal grass and Nutritional Balance Index (NBI) obtained by the method of Beaufils for combinations of methods choice of ratio order among nutrients ( $\mathrm{F}$ and $\mathrm{R}$ values) in the first growth using the norm of the first growth (a), in the first growth using the general norm (b), in the second growth using the norm of the second growth (c) and in the second growth using the general norm (d). 


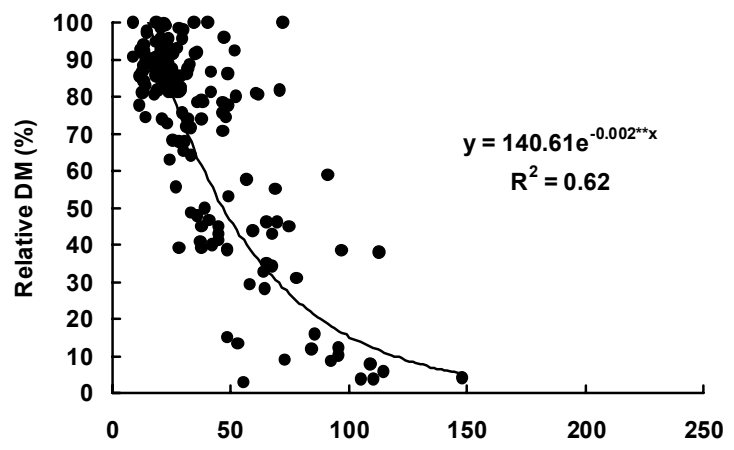

a)

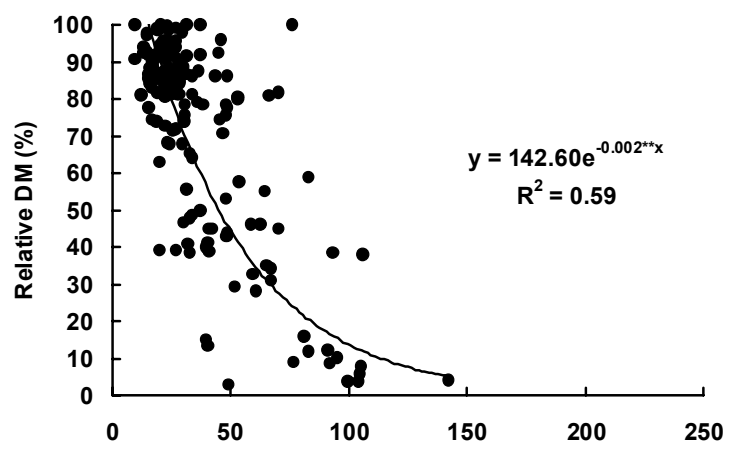

b)

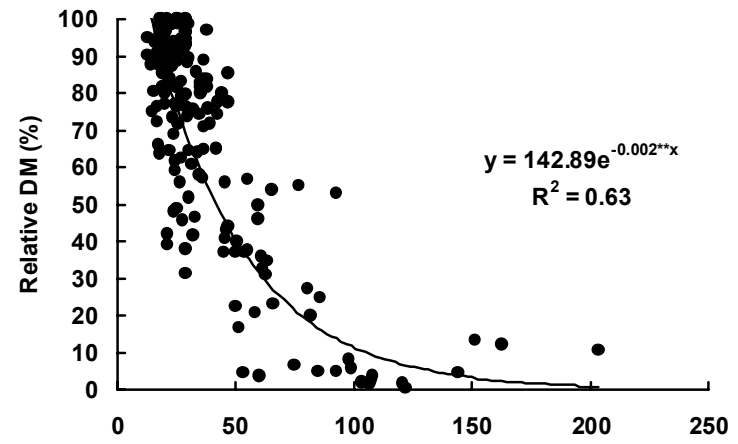

c)

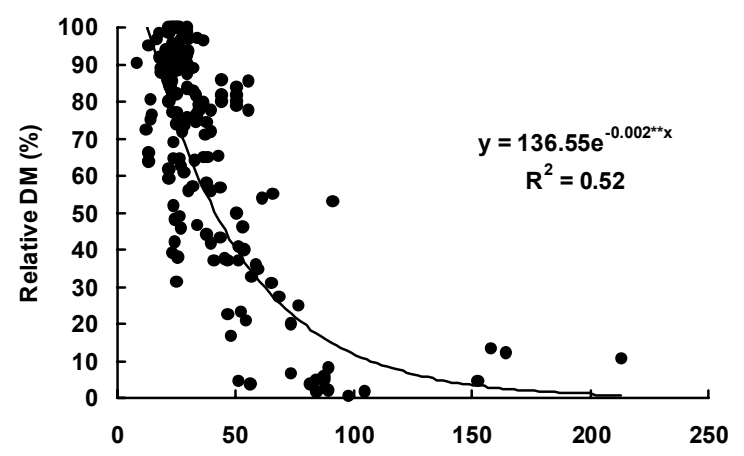

d)
NBI Jones F

NBI Jones F

NBI Jones F

NBI Jones F

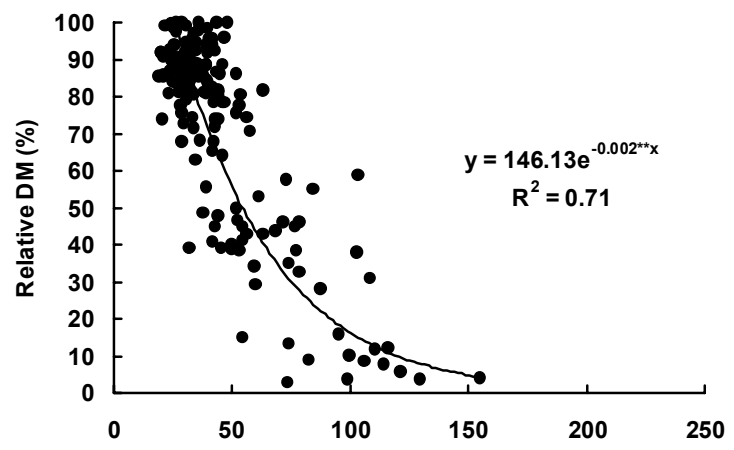

a)

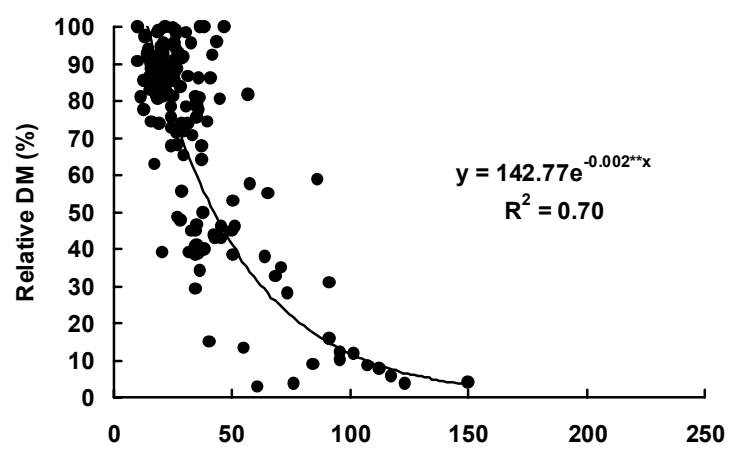

b)

NBI Jones R

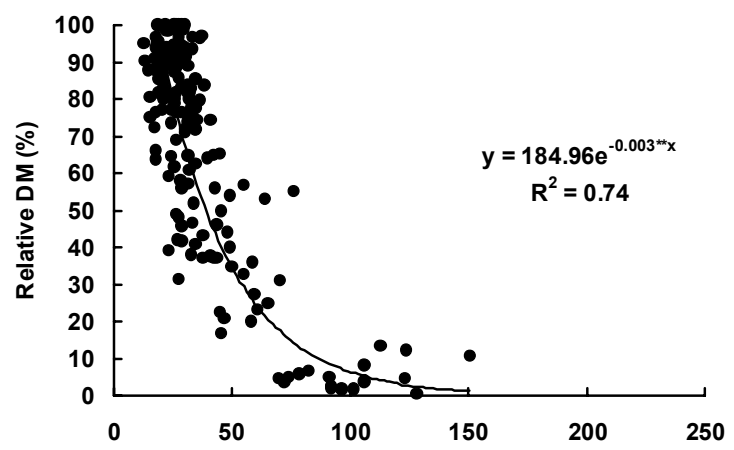

c)

NBI Jones R

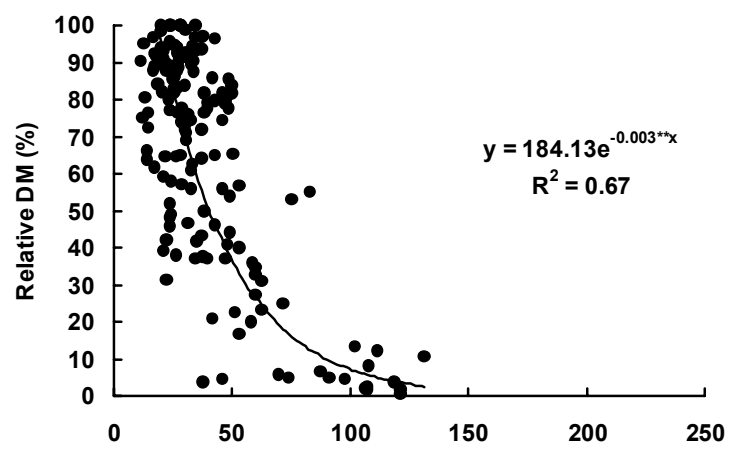

d)

NBI Jones R

Figure 2 - Relationship between the relative dry mass (DM) production of Signal grass and Nutritional Balance Index (NBI) obtained by the method of Jones for combinations of methods choice of ratio order among nutrients ( $\mathrm{F}$ and $\mathrm{R}$ values) in the first growth using the norm of the first growth (a), in the first growth using the general norm (b), in the second growth using the norm of the second growth (c) and in the second growth using the general norm (d). 


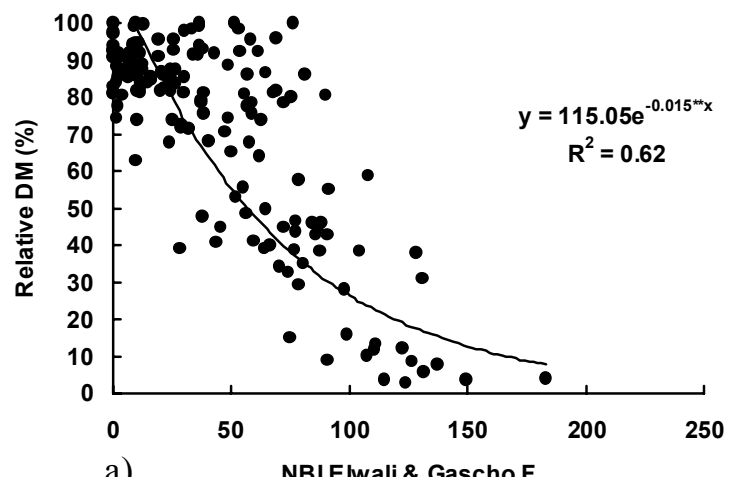

a)
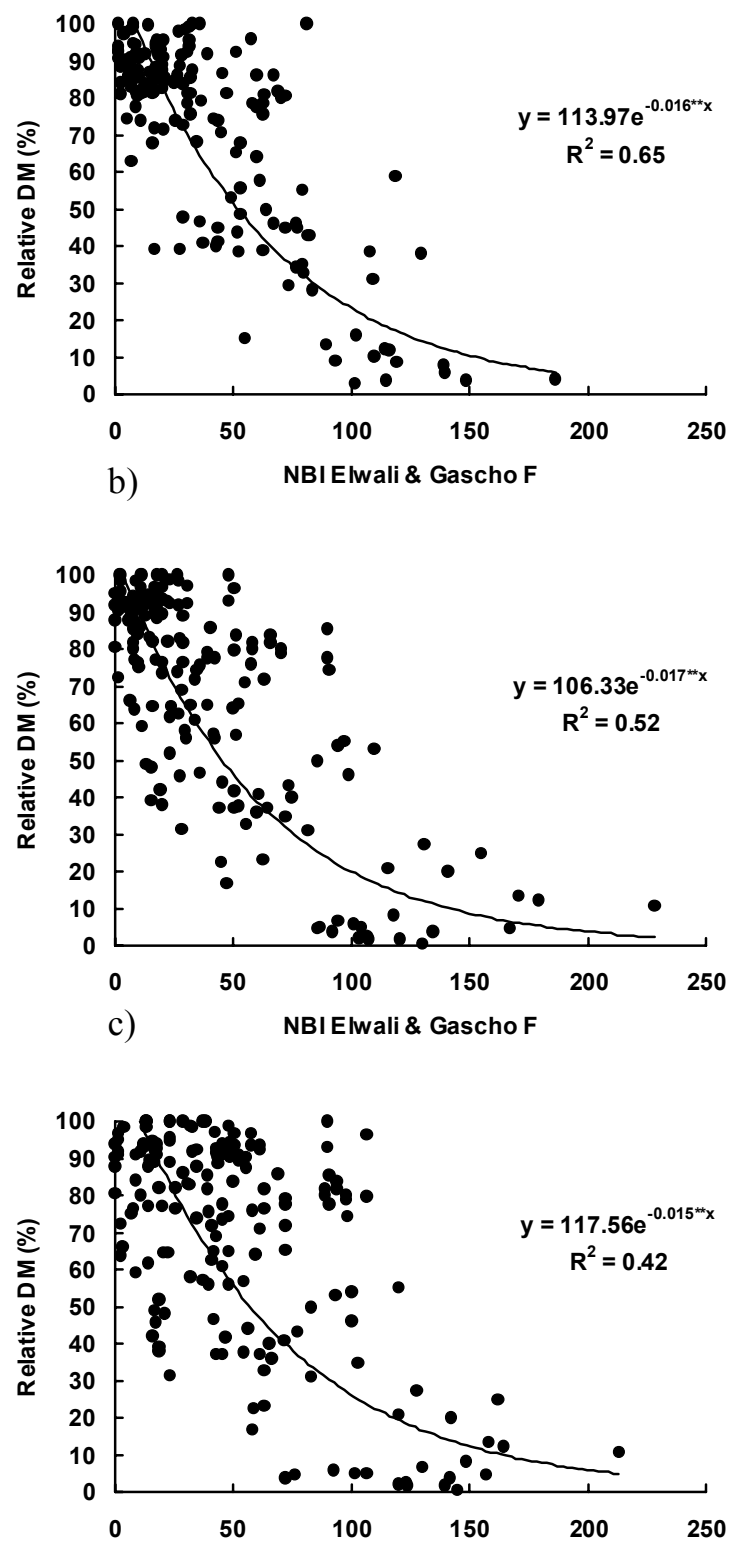

d)

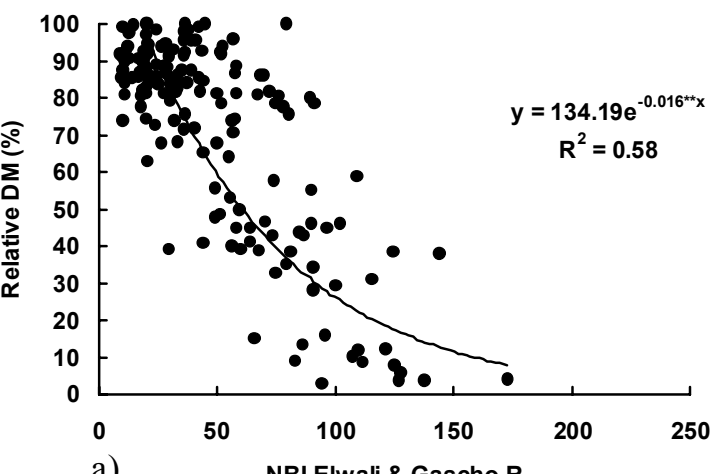

a)

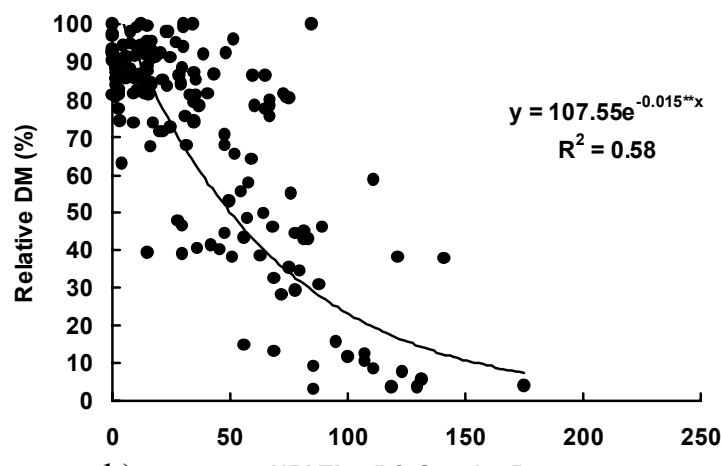

b) NBI Elwali \& Gascho R
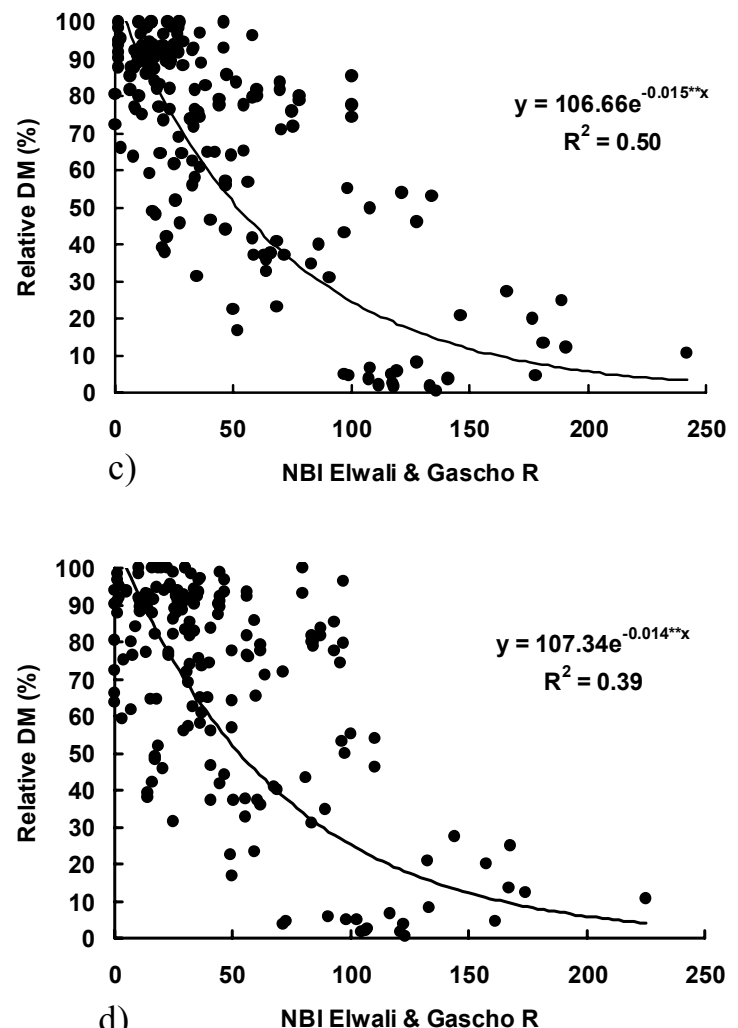

d) NBI Elwali \& Gascho R

Figure 3 - Relationship between the relative dry mass (DM) production of Signal grass and Nutritional Balance Index (NBI) obtained by the method of Elwali \& Gascho for combinations of methods choice of ratio order among nutrients (F and $\mathrm{R}$ values) in the first growth using the norm of the first growth (a), in the first growth using the general norm (b), in the second growth using the norm of the second growth (c) and in the second growth using the general norm (d). 
Table 2 - Percentage of agreement in nutritional diagnosis (deficiency, adequate and excess) between the sufficiency range criterion and the DRIS methods for combinations of criteria of choice of ratio order among nutrients ( $\mathrm{F}$ and $\mathrm{R}$ values) and DRIS indices (methods of Beaufils, Jones and Elwali \& Gascho), with results of the two growths of Signal grass.

\begin{tabular}{|c|c|c|c|c|c|c|}
\hline \multirow{2}{*}{ Nutrient } & \multicolumn{2}{|c|}{ Beaufils } & \multicolumn{2}{|c|}{ Jones } & \multicolumn{2}{|c|}{ Elwali \& Gascho } \\
\hline & $\mathrm{F}$ & $\mathrm{R}$ & $\mathrm{F}$ & $\mathrm{R}$ & $\mathrm{F}$ & $\mathrm{R}$ \\
\hline & $\ldots$ & -...... & - & - & $\ldots-\ldots$ & 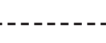 \\
\hline $\mathrm{N}$ & 70.83 & 70.83 & 62.50 & 79.17 & 70.83 & 70.83 \\
\hline $\mathrm{P}$ & 83.33 & 83.33 & 83.33 & 83.33 & 83.33 & 83.33 \\
\hline K & 100.00 & 100.00 & 100.00 & 100.00 & 100.00 & 100.00 \\
\hline $\mathrm{Ca}$ & 100.00 & 100.00 & 100.00 & 100.00 & 100.00 & 95.83 \\
\hline $\mathrm{Mg}$ & 83.33 & 87.50 & 91.67 & 79.17 & 87.50 & 87.50 \\
\hline S & 87.50 & 87.50 & 91.67 & 91.67 & 87.50 & 87.50 \\
\hline $\mathrm{Cu}$ & 100.00 & 100.00 & 100.00 & 100.00 & 100.00 & 100.00 \\
\hline $\mathrm{Fe}$ & 95.83 & 95.83 & 95.83 & 95.83 & 95.83 & 95.83 \\
\hline $\mathrm{Mn}$ & 87.50 & 87.50 & 87.50 & 87.50 & 87.50 & 87.50 \\
\hline $\mathrm{Zn}$ & 91.67 & 91.67 & 91.67 & 91.67 & 91.67 & 91.67 \\
\hline Average & 90.00 & 90.42 & 90.42 & 90.83 & 90.42 & 90.00 \\
\hline
\end{tabular}

The percentage of agreement between DRIS methods and the criterion of sufficiency range was used to define the best diagnosis method for Signal grass, considering all the nutrients evaluated in the experiment carried out with this grass collected at the Mundo Novo farm and grown with combinations of nitrogen and sulfur rates. For this, it was verified the number of samples with concentrations classified as deficient (below the appropriate), as appropriate and as in excess (above the appropriate) for the criterion of sufficiency range and the number of samples with indicative DRIS indices of deficiency (DRIS indices of the nutrient lower than zero and DRIS indices, in module, higher than the NBIa), of appropriate nutrition (DRIS indices lower than or equal to NBIa) and of excess (DRIS indices of nutrient above zero and DRIS indices, in module, higher than to NBIa) for the DRIS methods.

The variation in the percentage of agreement in the nutritional diagnosis varied between $62.5 \%$ and $100 \%$, among the evaluated models (Table 2). The number of agreements among the evaluated DRIS methods either by using the $F$ value or the $R$ value and the criterion of sufficiency range were similar. The lowest percentage of agreements for the diagnosis using DRIS and the sufficiency range criterion was obtained for the nitrogen. The results showed that for nitrogen the sufficiency range criterion identified greater number of deficient plants than the DRIS method.

Comparing the average of results obtained using both criteria of choice for the ratio order of nutrients $(\mathrm{F}$ value and $\mathrm{R}$ value), it was found similar results for the types of criteria, indicating that both can be used for Signal grass. On the other hand, Nick (1998) for coffee plants and Mourão Filho et al. (2002) for "Valencia" orange trees observed that the criterion of $\mathrm{R}$ value was better than the $\mathrm{F}$ value.

\section{ACKNOWLEDGEMENTS}

The authors gratefully acknowledge Waldssimiler Teixeira de Mattos for supplying part of the necessary data for this work, and Anacleto Ranulfo dos Santos, Plínio Marcos Frare and Renata Aparecida Martim for their help in conducting some of the experiments cited in this paper.

\section{REFERENCES}

BEAUFILS, E.R. Diagnosis and recommendation integrated system (DRIS). A general scheme for experimentation and calibration based on principles developed from research in plant nutrition. Pietermararitzburg, South Africa: University of Natal, 1973. 132p. (Soil Science Bulletin, 1).

BEVERLY, R.B.; A practical guide to the Diagnosis and Recommendation Integrated System (DRIS). Athens: Micro-Macro, 1991. 87p.

ELWALI, A.M.O.; GASCHO, G.J. Soil testing, foliar analysis, and DRIS as guide for sugarcane fertilization. Agronomy Journal, v.76, p.466-470, 1984.

GALLO, J.R.; HIROCE, R.; BATAGLIA, O.C.; FURLANI, P.R.; FURLANI, A.M.C.; MATTOS, H.B.; SARTINI, H.J.; FONSECA, M.P. Composição inorgânica de forrageiras do Estado de São Paulo. Boletim de Indústria Animal, v.31, p.115-137, 1974.

JONES, C.A. Proposed modifications of the diagnosis and recommendation integrated system (DRIS) for interpreting plant analysis. Communications in Soil Science and Plant Analysis, v. 12, p. 785-794, 1981.

LETZSCH, W.S. Computer program for selection of norms for use in the diagnosis and recommendation integrated system (DRIS). Communications in Soil Science and Plant Analysis, v.16, p.339-347, 1985.

LETZSCH, W.S.; SUMNER, M.E. Effect of population size and yield level in selection of diagnosis and recommendation integrated system (DRIS) norms. Communications in Soil Science and Plant Analysis, v.15, p.997-1006, 1984. 
MATTOS, W.T. Diagnose nutricional de potássio em duas espécies de Braquiária. Piracicaba: USP/ESALQ, 1997. 74p. (Dissertação Mestrado).

MATTOS, W.T. Avaliação de pastagem de capim-Braquiária em degradação e sua recuperação com suprimento de nitrogênio e enxofre. Piracicaba: USP/ESALQ, 2001. 97p. (Tese - Doutorado).

MONTEIRO, F.A. Concentração e distribuição de nutrientes em gramíneas e leguminosas forrageiras. In: SIMPÓSIO SOBRE MANEJO ESTRATÉGICO DA PASTAGEM, 2., Viçosa , 2004. Anais. Viçosa: UFV/DZO, 2004. p.71-107.

MONTEIRO, F.A.; MATTOS, W.T.; MARTIM, R.A. Partes da planta e diagnose nutricional de fósforo em Brachiaria decumbens. In: CONGRESSO BRASILEIRO DE CIÊNCIA DO SOLO, 25., Viçosa, 1995. Anais. Viçosa: SBCS, 1995. v.2, p.556-557.

MOURÃO FILHO, F.A.A. DRIS: Concepts and applications on nutritional diagnosis in fruit crops. Scientia Agricola, v.61, p.550-560, 2004.

MOURÃO FILHO, F.A.A.; AZEVEDO, J.C. DRIS norms for 'Valencia' sweet orange on three rootstocks. Pesquisa Agropecuária Brasileira, v.38, p. 85-93, 2003.

MOURÃO FILHO, F.A.A.; AZEVEDO, J.C.; NICK, J.A. Funções e ordem da razão dos nutrientes no estabelecimento de normas DRIS em laranjeiras 'Valência'. Pesquisa Agropecuária Brasileira, v.37, p.185$192,2002$.

NICK, J.A. DRIS para cafeeiros podados. Piracicaba: USP/ESALQ, 1998. 86p. (Dissertação - Mestrado).

SANTOS, A.R. Diagnose nutricional e resposta do capim-Braquiária submetido a doses de nitrogênio e enxofre. Piracicaba: USP/ESALQ, 1997. 115p. (Tese - Doutorado).

SANTOS, W.R. Métodos diagnósticos do equilíbrio nutricional dos macronutrientes em citros. Piracicaba: USP/ESALQ, 1997. 113p. (Dissertação - Mestrado).
SARRUGE, J.R.; HAAG, H.P. Análises químicas em plantas. Piracicaba: ESALQ, 1974. 54p.

SAS Institute Inc. SAS/STAT. User's guide, version 8.0. Cary, 2000.

SILVEIRA, C.P.; NACHTIGALL, G.R.; MONTEIRO, F.A. Norms for the diagnosis and recommendation integrated system for Signal grass. Scientia Agricola, v.62, 513-519, 2005.

SUMNER, M.E. Use of the DRIS system in foliar diagnosis of crops at high yield levels. Communications in Soil Science and Plant Analysis, v.8, p.251-268, 1977.

WADT, P.G.S. Os métodos da chance matemática e do sistema integrado de diagnose e recomendação (DRIS) na avaliação nutricional de plantios de eucalipto. Viçosa: UFV, 1996. 123p. (Tese - Doutorado).

WADT, P.G.S.; NOVAIS, R.F.; ALVAREZ VENEGAS, V.H.; FONSECA, S.; BARROS, N.F. Valores de referência para macronutrientes em eucalipto obtidos pelos métodos DRIS e chance matemática. Revista Brasileira de Ciência do Solo, v.22, p.685-692, 1998.

WADT, P.G.S.; NOVAIS, R.F.; ALVAREZ VENEGAS, V.H.; BRAGANÇA, S.M. Alternativas de aplicação do "DRIS" à cultura de café conilon (Coffea canephora Pierre). Scientia Agricola, v.56, p.83-92, 1999.

WALWORTH, J.L.; SUMNER, M.E. The diagnosis and recommendation integrated system (DRIS). Advances in Soil Science, v.6, p.149-188, 1987.

WERNER, J.C.; PAULINO, V.T.; CANTARELLA, H.; QUAGGIO, J.A. Forrageiras. In: RAIJ, B. van; CANTARELLA, H.; QUAGGIO, J.A.; FURLANI, A.M.C. (Ed.) Recomendações de adubação e calagem para o Estado de São Paulo. Campinas: Instituto Agronômico, 1996. 285p. (Boletim Técnico, 100).

$\overline{\text { Received April 08, }}, 2005$

Accepted October 05, 2005 